\title{
PHYSICAL QUALITY OF SOIL IN MECHANIZED THINNING OF Eucalyptus sp.
}

\author{
Francieli de Vargas ${ }^{1 *}$, Catize Brandelero², Denise Andréia Szymczak ${ }^{3}$, Lúcio de Paula Amaral², Mirta Teresinha \\ Petry $^{2}$, Valmir Werner ${ }^{2}$ \\ ${ }^{1}$ Universidade Federal de Santa Maria, Programa de Pós-Graduação em Engenharia Florestal, Santa Maria, Rio Grande do Sul, Brasil - \\ devargasfrancieli@gmail.com*. \\ ${ }^{2}$ Universidade Federal de Santa Maria, Departamento de Engenharia Rural, Santa Maria, Rio Grande do Sul, Brasil - \\ catizebrandelero@gmail.com; amaralufsm@gmail.com; mirta.petry@gmail.com; valmirw1@gmail.com. \\ ${ }^{3}$ Universidade Tecnológica Federal do Paraná, Departamento de Engenharia Ambiental, Francisco Beltrão, Paraná, Brasil - \\ denisea@utfpr.edu.br.
}

Received for publication: 22/04/2019 - Accepted for publication: 11/07/2019

\begin{abstract}
Resumo
Qualidade física do solo em desbaste mecanizado de Eucalyptus sp. O tráfego de máquinas é a principal causa de compactação dos solos florestais, pois ocorrem deformações no solo, ocasionadas por pressões exercidas das pelas máquinas, tanto no momento do corte, como no baldeio da madeira. Nesse sentido, este trabalho teve por objetivo avaliar a compactação do solo, causada pelo tráfego de máquinas, na operação de desbaste mecanizado de Eucalyptus saligna Smith. Foi realizado em povoamento florestal, no município de Butiá, RS Alterações em propriedades físicas do solo foram avaliadas; em três tratamentos: sem tráfego; após o corte; e após $\Theta$ baldeio da madeira. Foram realizados o inventário florestal e a coleta de amostras indeformadas de solo, para a determinação da microporosidade, macroporosidade e densidade. O delineamento experimental utilizado foi o inteiramente casualisado, de arranjo bifatorial, com parcelas subdivididas. Para a comparação dos atributos físicos, foi utilizado o teste de Tukey $(\mathrm{p} \leq 0,05)$. Os resultados evidenciaram um acréscimo nos valores de densidade do solo, principalmente no tratamento após baldeio e redução nos macroporos, com valores próximos e abaixo do limite considerável como prejudicial ao desenvolvimento das plantas. O conhecimento das deformações do solo ocasionada pelas operações florestais contribui para a melhoria dos processos futuros, com o intuito de balizar a qualidade física do solo, a fim de oferecer condições benéficas ao crescimento das plantas.

Palavras-chave: Tráfego de máquinas; Atributos do solo; Solos florestais; Mecanização.
\end{abstract}

\begin{abstract}
The traffic of machines is the main cause of compaction of forest soils, causing soil deformations, due to the pressures exerted by the machines, both at the time of cutting and in the transshipment of wood. In this sense, this work had as objective to evaluate soil compaction, caused by the traffic of machines, in the mechanized thinning operation of Eucalyptus saligna Smith. This study was carried out in forest stands, in the municipality of Butiá, RS. Changes in soil physical properties were evaluated in three treatments: with no traffic; after cutting; and after wood transshipment. The forest inventory and collection of undisturbed soil samples were carried out to determine microporosity, macroporosity and bulk density. The experimental design was the completely randomized, in a bifactorial arrangement, with subdivided plots. For the comparison of the physical attributes, the Tukey test $(\mathrm{p} \leq 0.05)$ of significance was used. The results evidenced increase in soil density values, mainly in the treatment after transshipment=and decrease in macropores, with values close to and below the limit considerable as detrimental to the development of the plants. The knowledge of soil deformations caused by forest operations contributes to the improvement of future processes aiming to guide the physical quality of the soil, in order to offer beneficial conditions to the growth of the plants.

Keywords: Traffic of machines; Soil attributes; Forest soils; Mechanization.
\end{abstract}

\section{INTRODUCTION}

In 2016, Brazil led the global ranking of forest productivity, with an average of $35.7 \mathrm{~m}^{3} / \mathrm{ha}$ for Eucalyptus plantations sp. (IBÁ, 2017). This potential in the forestry sector contributed to the increase in the area planted in recent years and to the mechanization of forest operations. Lopes et al. (2011) point out that the traffic of machines is the main cause for the compaction of forest soils, due to their disorderly use.

Traffic of machines that perform the harvesting and transshipment of wood leads to increase in soil density, characterizing its compaction (RICHART et al., 2005). With soil compaction there may be difficulty for the growth and compromise in the distribution of plant roots (SPERANDIO; CECÍLIO, 2017), reduction of the hydraulic conductivity (SZYMCZAK et al., 2014), reduction of soil water storage capacity (ROSA et al., 2018.), limitation of adsorption and absorption of nutrients by plants (RICHART et al., 2005). Besides the change in porosity, it results in decrease of pore size (SAMPIETRO; LOPES, 2016) and increase in the values of soil resistance to penetration (RODRIGUES et al., 2018).

FLORESTA, Curitiba, PR, v. 50, n. 4, p. 1837 - 1843, out/dez 2020

Vargas, F. et.al.

ISSN eletrônico 1982-4688

DOI: $10.5380 / \mathrm{rf} . \mathrm{v} 50$ i4. 66186 
Dias Junior et al. (2005) warn that one of the limitations to achieve sustainable forest development is related to the machines traffic during harvesting and wood transshipment operations. It causes soil compaction, as the management system employed and the intensity of machine traffic result in changes in physical characteristics of the soil.

Although there are studies in this field, evaluating the relationship of mechanical harvesting systems in forest soil compaction, it is noted that investigations of mechanized thinning operations and their interrelationship with the soil are still uncommon in Brazil. The thinning operation is critical to the success of forests at the end of the rotation with a higher volumetric increase, quality of logs and for their sale with a higher added value. This study aimed to analyze the effects of mechanized thinning operation on the physical properties of the soil.

\section{MATERIALS AND METHODS}

The field study was developed in a plantation of Eucalyptus saligna Smith submitted to the second commercial thinning, located in the municipality of Butiá, in Rio Grande do Sul, at the geographical coordinates $30^{\circ} 11^{\prime} 5.24^{\prime \prime} \mathrm{S}$ and $51^{\circ} 58^{\prime} 18.74^{\circ} \mathrm{W}$. The climate of the municipality is classified as the wet subtropical type Cfa (Köppen), with average annual temperature of $23^{\circ} \mathrm{C}$ and annual rainfall index of approximately $1,652.6 \mathrm{~mm}$ (WREGE et al., 2012). Planting took place in 2008, spaced $2.5 \mathrm{~m} \mathrm{x} 3.0 \mathrm{~m}$. In 2018, afforestation stand presented DAP $23.35 \mathrm{~cm}$, average height of $20.7 \mathrm{~m}$ and individual average volume of of $0.2771 \mathrm{~m}^{3}$.

Local soils were classified as red Ultisol (STRECK et al., 2002), with sandy-clay-loam texture in site A and sandy loam in site B. The particle size analysis was by the pipette method, proposed by EMBRAPA (2017), as well as for the determination of density, macroporosity and soil microporosity.

Soil characteristics in a traffic-free area (control) were evaluated after cutting and after transport. Cutting of trees was carried out by a mat-base machine of the manufacturer Hyundai, engine Cummins QSB4.5 tier III, with head processor model 6000B, by Log Max. Transport was performed with a Valtra tractor, model BH180, engine AGCO Power 620 DS, power of $139 \mathrm{~kW}$. A trailer with crane was attached to the tractor for the loading of wood, from Penzsaur manufacturer, model 7.60W, with a maximum capacity of 12 tons of cargo.

Mechanized thinning employed in the studied place was constituted by two systems: systematic (every four rows of trees, a line cut in a continuous way) and selective (considering trees with defects, tortuosity, injuries and the ones of lower layer).

Assessment of effects caused by the traffic of machines occurred in two locations (A and B), with sizes of $15 \mathrm{~m}$ x $50 \mathrm{~m}$, with distance of $230 \mathrm{~m}$ between them, located in the same field. For each location-three collections of undisturbed soil samples were performed for each treatment, in the machines traffic track. Determinations of density, macroporosity and microporosity of soil volumetric rings were used in four defined layers $(0 \mathrm{to} 5 \mathrm{~cm}, 5$ to $10 \mathrm{~cm}, 10$ to $20 \mathrm{~cm}$, and 20 to $30 \mathrm{~cm}$ ).

The experiment was delineated as a completely randomized design (CRD) of bifactorial arrangement, subdivided plots, with three replications. Sites for the study were defined as a first factor, and as a second factor the treatments: with no traffic; after cutting; and, after transshipment. Data normality was verified by the ShapiroWilk test (1965), and homogeneity of the variances using Bartlett's test. Soil physical properties were evaluated with the Tukey test $(\mathrm{p} \leq 0.05)$. Interpretation of the results, in the Figures, the means followed by the same capital letter do not differ statistically from each other.

\section{RESULTS}

In the bifactorial analysis of the soil physical attributes, site effect was observed for all layers evaluated in the attributes soil density and microporosity. For the soil macroporosity attribute site effect occurred only in the 0 to $5 \mathrm{~cm}$ layer.

Site A presented $628.7 \mathrm{~g} . \mathrm{kg}^{-1}$ of sand, $198.8 \mathrm{~g} \mathrm{~kg}^{-1}$ of silt and $172.5 \mathrm{~g}$. $\mathrm{kg}^{-1}$ of clay, being classified as sandy-clay-loam texture. Site B showed, on average, $11 \%$ more clay, being classified as sandy loam. Soil moisture at the sampling time was of $0.33 \mathrm{~kg} . \mathrm{kg}^{-1}$ and $0.38 \mathrm{~kg} . \mathrm{kg}^{-1}$, respectively, in sites A and $\mathrm{B}$. Under these conditions, the mechanized thinning presented effect on the ground, showing that the traffic of machinery causes compaction. The layer from 0 to $5 \mathrm{~cm}$ presented significant difference between the treatments for the two sites (Figure 1). At site $\mathrm{A}$, it was observed an increase in bulk density of $4.39 \%$ after cutting $\left(\mathrm{T}_{1}\right)$ and of $8.19 \%$ after the transshipment $\left(\mathrm{T}_{2}\right)$, compared to no traffic condition $\left(\mathrm{T}_{0}\right)$. At site $\mathrm{B}$, the highest effect was after the treatment $\mathrm{T}_{2}$, showing increase of $11.85 \%$ in relation to $\mathrm{T}_{0}$.

For the layer from 5 to $10 \mathrm{~cm}$, there was no difference between treatments at location A. For the same layer at site B there was significant difference, with $8 \%$ increase in soil density after the transshipment $\left(\mathrm{T}_{2}\right)$ in relation to $\mathrm{T}_{0}$. Analyzing the treatments at each location, it was found that in the layers from 10 to $20 \mathrm{~cm}$ and from 20 to $30 \mathrm{~cm}$ there was no significant difference (Figure 1). It can be inferred that the deeper layers have less change in physical properties caused by machinery traffic.

FLORESTA, Curitiba, PR, v. 50, n. 4, p. 1837 - 1843, out/dez 2020.

Vargas, F. et.al.

ISSN eletrônico 1982-4688

DOI: $10.5380 /$ rf.v50 i4. 66186 


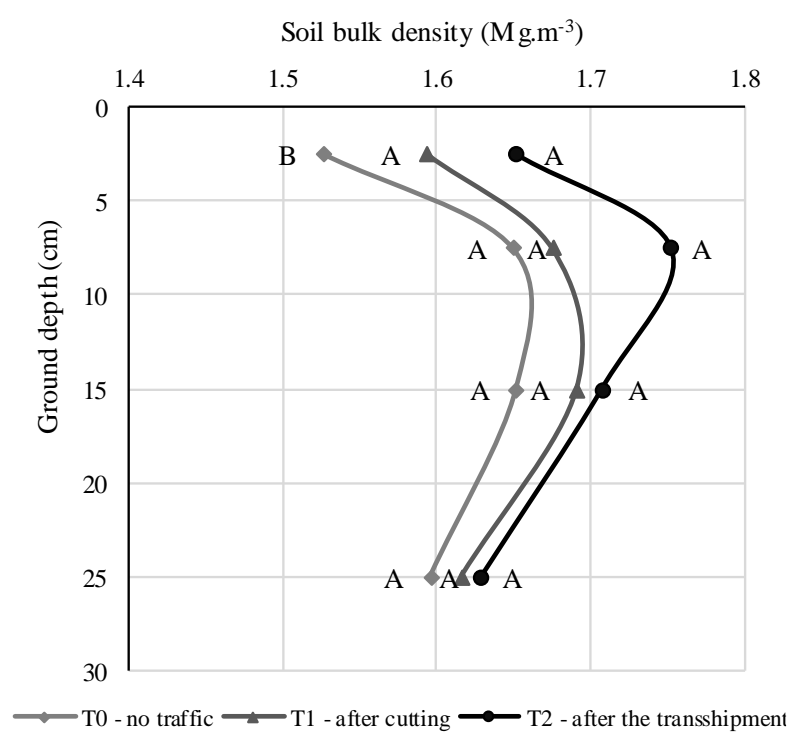

(a)

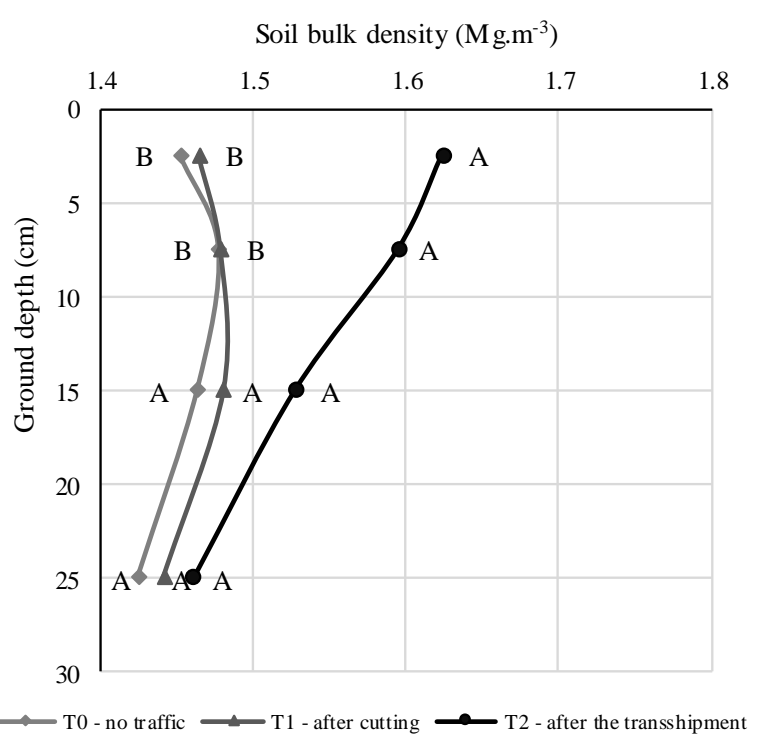

(b)

Figure 1. Mean values of soil bulk density $\left(\mathrm{Mg}_{\mathrm{m}} \mathrm{m}^{-3}\right)$ in the two sites, for treatments of mechanized thinning of Eucalyptus saligna.

Figura 1. Valores médios de densidade do solo $\left(\mathrm{Mg}_{\mathrm{m}} \mathrm{m}^{-3}\right)$ nos dois locais, para os tratamentos de desbaste mecanizado de Eucalyptus saligna.

At site B, the average soil density in the layer 0 to $5 \mathrm{~cm}$, exceeded the density considered critical for clay soils, ranging from 1.40 to $1.60 \mathrm{Mg} . \mathrm{m}^{-3}$, according to Reichert et al. (2003). At location A, soil density was higher than $1.60 \mathrm{Mg} \mathrm{m}-3$ in most of the observations, with an initial condition of $1.527 \mathrm{Mg} \mathrm{m}^{-3}$.

Soil macroporosity showed a reduction in the layers 0 to $5 \mathrm{~cm}$ and 5 to $10 \mathrm{~cm}$, but was significant only at site B (Figure 2b), on all layers. For layer 0 to $5 \mathrm{~cm}$, there was a reduction of $53.64 \%$ after the transport $\left(\mathrm{T}_{2}\right)$ as compared to no traffic $\left(\mathrm{T}_{0}\right)$. On the layer 5 to $10 \mathrm{~cm}$; the values of macro pores decreased $29.17 \%$ after transshipment $\left(\mathrm{T}_{2}\right)$. This treatment showed a mean value of $0.070 \mathrm{~m}^{3} . \mathrm{m}-3$ in the first layer and $0.102 \mathrm{~m}^{3} . \mathrm{m}^{-3} \mathrm{on}$ the second layer, with values that may be regarded as harmful for the growth and development of plants.

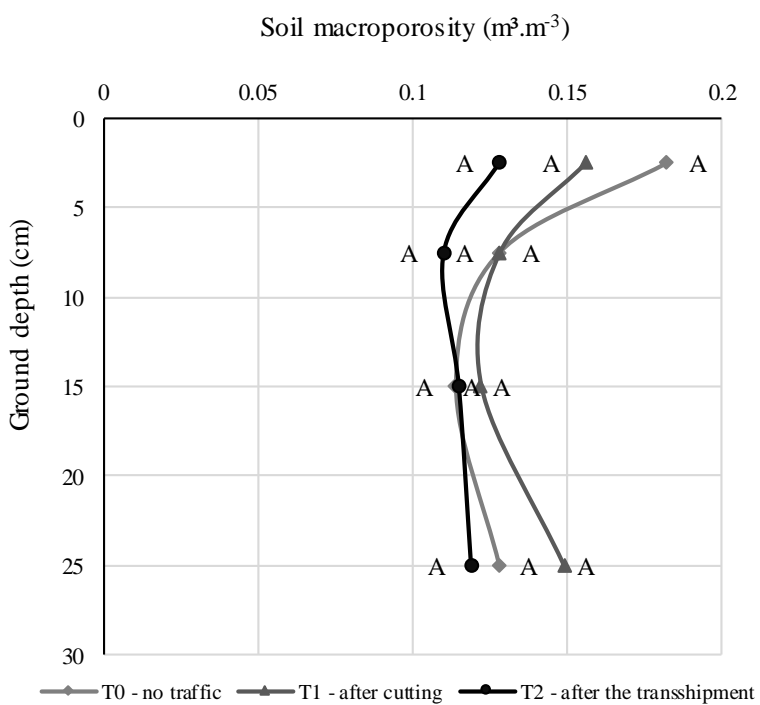

(a)

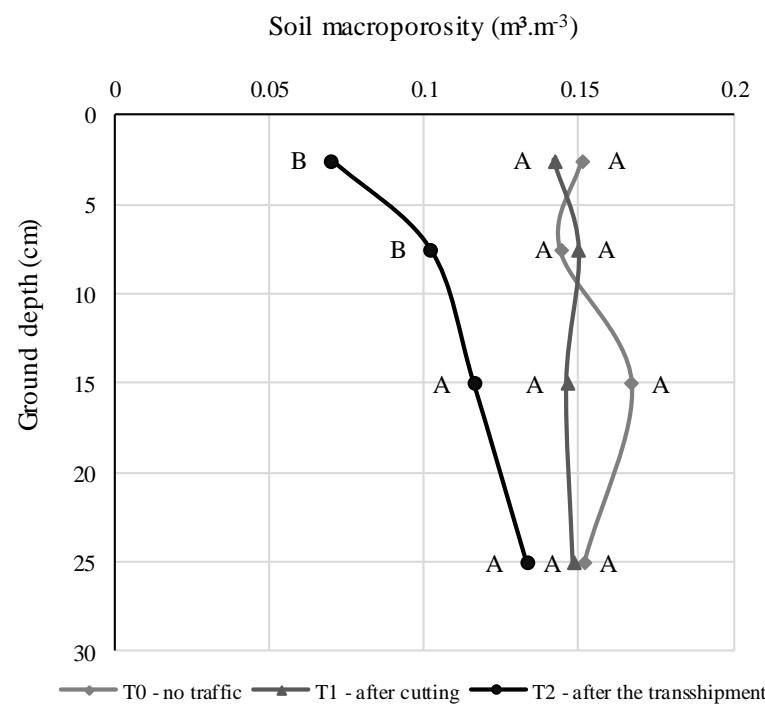

(b)

Figure 2. Mean values of soil macroporosity $\left(\mathrm{m}^{3} \cdot \mathrm{m}^{-3}\right)$ at sites A and B, for treatments of mechanized thinning of Eucalyptus saligna.

FLORESTA, Curitiba, PR, v. 50, n. 4, p. 1837 - 1843, out/dez 2020

Vargas, F. et.al.

ISSN eletrônico 1982-4688

DOI: $10.5380 /$ rf.v50 i4. 66186 
Figura 2. Valores médios de macroporosidade do solo $\left(\mathrm{m}^{3} \cdot \mathrm{m}^{-3}\right)$ nos locais A e B, para os tratamentos de desbaste mecanizado de Eucalyptus saligna.

Soil microporosity no significant difference at location A. For location B there was difference only for layer 5 to $10 \mathrm{~cm}$ (Figure 3b). It was observed an increase in micropore values for the layer 0 to $5 \mathrm{~cm}$. As can be seen in Figure 3, soil microporosity did not present a continuous behavior, as there was no increase and/or reduction with the traffic of machines on all layers, with little or no inference in the compaction process.

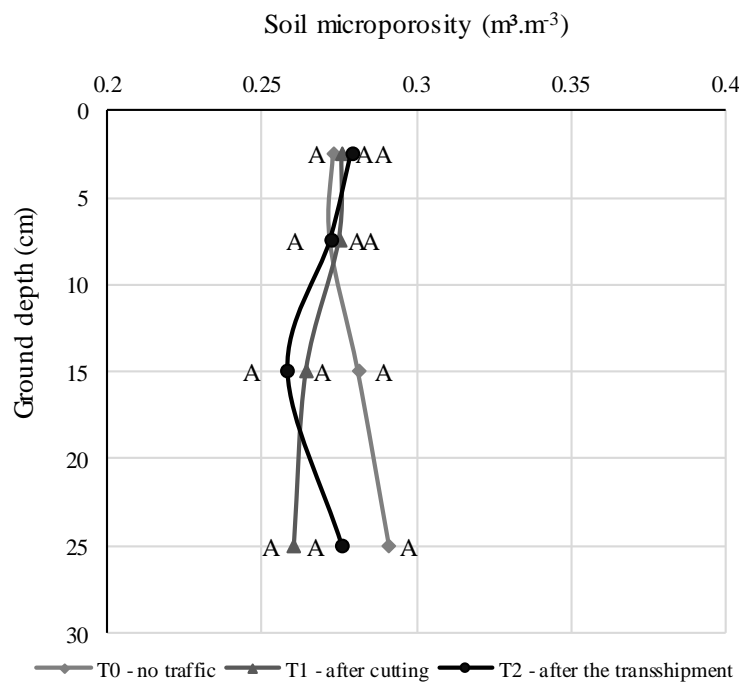

(a)

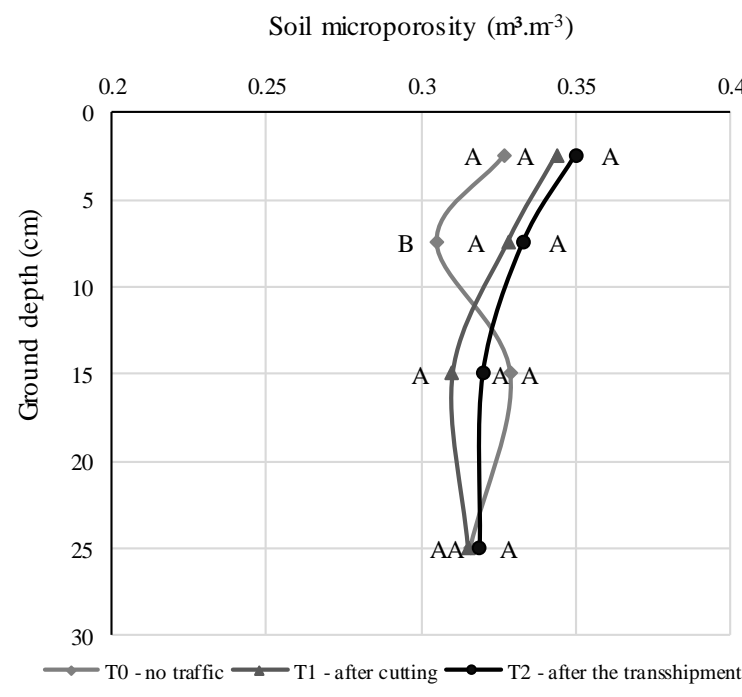

(b)

Figure 3. Mean values of soil microporosity $\left(\mathrm{m}^{3} \cdot \mathrm{m}^{-3}\right)$ in both sites, for treatments of mechanized thinning of Eucalyptus saligna.

Figura 3. Valores médios de microporosidade do solo $\left(\mathrm{m}^{3} \cdot \mathrm{m}^{-3}\right)$ nos dois locais, para os tratamentos de desbaste mecanizado de Eucalyptus saligna.

\section{DISCUSSION}

Soil density showed a different behavior at each location, due to the soil texture. At site B, with $11 \%$ more clay, there was greater susceptibility to the machinery traffic, with effect down to the depth of $10 \mathrm{~cm}$. Luciano et al. (2012) emphasize that soil classes have different behavior when subjected to compaction, depending on the texture, mineralogy, organic matter and moisture. Moreover, they mention that clay and organic matter retain more water than silt and sand fractions, generating a predisposition to compaction.

Forest harvesting with a harvester and a forwarder in plantation of Pinus taeda showed compaction until $10 \mathrm{~cm}$ of soil depth, along the tracks of traffic of the machines in a study by Szymczak et al. (2014). Even with small changes in soil density Sampietro et al. (2015) stated that traffic can cause negative consequences, such as reduced porosity and water flow in the soil.

Sampietro and Lopes (2011) emphasize that the surface layer from 0 to $15 \mathrm{~cm}$ presents high susceptibility to changes introduced by the traffic of machines when compared to the deeper layers. In their studies, Sampietro et al. (2015) noted that the increase in density for the soil surface layer (0 to $15 \mathrm{~cm}$ ) was $73.4 \%$ higher when compared with the deeper layers. Szymczak et al. (2014) argue that it may occur a dissipation of the pressure applied by the traffic of the machines in the soil, not reaching the deeper layers to a considerable level. Rodrigues et al. (2018) observed an increase in density and decrease in soil porosity in the soil surface layers after machine traffic in the harvest of Eucalyptus grandis, with values above critical limits in the tracks of machine traffic.

In the process of soil compaction, one of the main consequences is the alteration of soil porosity values, especially with a reduction of macro pores. According to Cambi et al. (2015), the reduction in macroporosity implies lower availability of oxygen and water to soil microorganisms and plants, with negative effect on soil ecology and forest productivity. For Seixas (1997), the macropores are responsible for quickly draining the ground after rain or irrigation, besides its aeration. The reduction of the macropores can cause an imbalance in these aspects of soil functionality.

For Klein and Libardi (2002) the transformation of macropores into micropores by the decreasing of void spaces seems to be one of the effects of soil compaction. Related to this and with the increase in soil density,

FLORESTA, Curitiba, PR, v. 50, n. 4, p. 1837 - 1843, out/dez 2020

Vargas, F. et.al.

ISSN eletrônico 1982-4688

DOI: $10.5380 /$ rf.v50 i4. 66186 
changes can occur in the process of diffusion of gases. Seixas (1997) reports that with smaller values of $10 \%$ of macropores, the diffusion of gas can be null in the soil. Furthermore, Reichert et al. (2009), consider $0.10 \mathrm{~m}^{3} \mathrm{~m}^{-3}$ as a minimum value of macropores so there is satisfactory growth and development of plants.

Szymczak et al. (2014) observed a decrease in soil macroporosity values of 60 and $50 \%$, respectively, in the layers 0 to 5 and 5 to $10 \mathrm{~cm}$, caused by the forest machines harvester and forwarder in their study of soil compaction in harvesting of Pinus taeda. Traffic of machines is influenced significantly macroporosity values in the layer of up to $10 \mathrm{~cm}$; in a study by Mazurana et al. (2013), indicating in the fallow system the lowest capacity to withstand disturbances. The macropores are highly modified and indicate a reduction in the soil aeration, as well as an increase in soil density, resulting in its compaction (REICHERT et al., 2003).

For Silva et al. (2011), the volume and the dimension of the pores must be adequate to meet the needs of the crop, such as: the entering, movement and retention of water and air in the soil. Mazurana et al. (2013) reported that the decrease of macroporosity values may be of disadvantage to growth and productivity of plants Moreover, with pores that were oriented parallel to the ground surface, without vertical continuity, they result in less effective infiltration of water and deep root development (GONÇALVES, MORAES, 2012).

If total transformation of macropores into micropores does not occur in the soil compaction process, micropores may change in structure and become less efficient for the physical quality of the soil, especially in relation to water retention. Seixas (1997) points out that water is retained in the micropores under higher tensions, and thus could be unavailable to plants.

Martins et al. (2002), in a study of four forest stands (Pinus sp., Eucalyptus sp., Hevea brasiliensis and native forest), about the structural quality of the soil, found that microporosity values were not different between the stands. Regarding to macroporosity, they found that only in the native forest there was no values below the ideal conditions $\left(0.10 \mathrm{~m}^{3} \cdot \mathrm{m}^{-3}\right)$. Nascimento et al. (2019) found that in integration systems of crop-livestock-forest, especially the forestry component affects negatively the physical condition of the soil, in layers from $5 \mathrm{~cm}$ to 10 $\mathrm{cm}$ and 20 to $30 \mathrm{~cm}$.

The effects of compaction on the physical attribute of microporosity varies according to the type of soil and evaluated conditions. Lopes et al. (2011) found no significant difference in porosity and aeration porosity, after the traffic of a skidder, with different types of wheel-sets. In a study by Rosa et al. (2018) significant changes were observed in the attribute of soil macro and microporosity in Argisol, with the cultivation of Eucalyptus dunnii. Mazurana et al. (2013) also observed a difference in micropore values before and after the traffic, but only in the layer of up to $5 \mathrm{~cm}$ in the condition of fallow. According to Holthusen et al. (2018), inadequate management of soil with increase in the mass of the machines used and the intensity of traffic threaten the functionality of soils.

The mechanized thinning compromised the physical quality of the soil, especially in relation to the macropores, by decreasing them, with the increase of soil density. It can affect the functionalities of this soil in the root distribution in the profile, aeration, the retention and infiltration of water, as well as in other soil physical properties. These way the compaction of the soil, after the passage of the machines, is evidenced.

\section{CONCLUSIONS}

- As a result of the changes in soil physical properties along the track of the traffic of machines, in mechanical thinning operation, it is concluded that there was soil compaction. This changes are associated with the pressures of the machinery and wood loading.

- In the attribute soil density there was the effect of the traffic of machinery. The transshipment of wood influenced up to a depth of $20 \mathrm{~cm}$.

- Macropores were affected by the traffic of machines, especially in the surface layer, whereas the micropores did not change to a significant level. The traffic of machinery is capable of compromising the micropores functionality, especially in the aspect of water retention, hindering the development of plants.

\section{ACKNOWLEDGEMENTS}

This research was conducted with the support of CAPES (Coordination for the Support of Research and Higher Education) and of UFSM (Federal University of Santa Maria).

\section{REFERENCES}

DIAS JUNIOR, M. DE S.; LEITE, F. P.; LASMAR JÚNIOR, E.; ARAÚJO JUNIOR, C. F. Traffic effects on the soil preconsolidation pressure due to eucalyptus harvest operations. Scientia Agricola, Piracicaba, v. 62, n. 3, p. $248-255,2005$.

EMBRAPA. Manual de métodos de análise de solo. Brasília: EMBRAPA, 3. ed. 2017, 573 p.

FLORESTA, Curitiba, PR, v. 50, n. 4, p. 1837 - 1843, out/dez 2020.

Vargas, F. et.al.

ISSN eletrônico 1982-4688

DOI: $10.5380 /$ rf.v50 i4. 66186 
GONÇALVES, F. C.; MORAES, M. H. Porosidade e infiltração de água do solo sob diferentes sistemas de manejo. Irriga, Botucatu, v. 17, n. 3, p. 337 - 345, 2012.

HOLTHUSEN, D.; BRANDT, A. A.; REICHERT, J. M.; HORN, R. Soil porosity, permeability and static and dynamic strength parameters under native forest/grassland compared to no-tillage cropping. Soil and Tillage Research, Amsterdam, v. 177, p. 113 - 124, 2018.

INSTITUTO BRASILEIRO DE ÁRVORES - IBÁ. Resultado Anual. 2017, Brasília. Disponível em: <https://iba.org/images/shared/Biblioteca/IBA_RelatorioAnual2017.pdf>. Acesso em: 09/10/2018.

KLEIN, V. A.; LIBARDI, P. L. Densidade e distribuição do diâmetro dos poros de um Latossolo Vermelho, sob diferentes sistemas de uso e manejo. Revista Brasileira de Ciência do Solo, Viçosa, v. 26, n. 4, p. 857 - 867 , 2002.

LOPES, E. S.; SAMPIETRO, J. A.; PEREIRA, A. L. N.; OLIVEIRA, D. de. Compactação de um Latossolo submetido ao tráfego de Skidder com diferentes rodados. Floresta, Curitiba, v. 41, n. 3, p. 471 - 480, 2011.

LUCIANO, R. V.; ALBURQUERQUE, J. A.; COSTA, A. da; BATISTELLA, B.; WARMLinG, M. T. Atributos físicos relacionados a compactação de solos sob vegetação nativa em região de altitude no sul do Brasil. Revista Brasileira de Ciência do Solo, Viçosa, v. 36, p. 1733 - 1744, 2012.

MARTINS, S. G.; SILVA, M. L. N.; CURI, N.; FERREIRA, M. M. Avaliação de atributos físicos de um Latossolo vermelho distroférrico sob diferentes povoamentos florestais. Cerne, Lavas, v. 8, n. 1, p. 32 - 41, 2002.

MAZURANA, M.; FINK, J. R.; SILVEIRA, V. H. de.; LAVIEN, R.; ZULPO, L.; BREZOLIN, D. Propriedades físicas do solo e crescimento de raízes de milho em um Argissolo vermelho sob tráfego controlado de máquinas. Revista Brasileira de Ciência do Solo, Viçosa, v. 37, n. 5, p. 1185 - 1195, 2013.

NASCIMENTO, D. M. do.; CAVALIERI-POLIZELI, K. M. V.; SILVA, A. H. da.; FAVARETTO, N.; PARRON, L. M. Soil physical quality under long-term integrated agricultural production systems. Soil and Tillage Research, Amsterdam, v. 186, p. 292 - 299, 2019.

REICHERT, J. M.; REINERT, D. J.; BRAIDA, J. A. Qualidade dos solos e sustentabilidade de sistemas agrícolas. Ciência e Ambiente, Santa Maria, v. 27, p. 29 - 48, 2003.

REICHERT, J. M.; SUZUKI, L. E. A. S.; REINERT, D. J.; HORN, R.; HÂKANSSON, I. Reference bulk density and critical degree-of-compactness for no-till crop production in subtropical highly weathered soils. Soil and Tillage Research, Amsterdam, v. 102, n. 2, p. 242 - 254, 2009.

RICHART, A.; TAVARES FILHO, J.; BRITO, O. R.; LLANILLO, R. F.; FERREIRA, R. Compactação do solo: causas e efeitos. Semina: Ciências Agrárias, Londrina, v. 26, n. 3, p. 321 - 344, 2005.

RODRIGUES, C. K.; LOPES, E. da. S.; POLIZELI, K. M. V. C.; MULLER, M.L. Soil Compaction Duo to Wood Harvesting Traffic at Different Extraction Distances. Floram - Floresta e Ambiente, Rio de Janeiro, v. 25, n. 2, p. $1-8,2018$.

ROSA, S. F. da.; REINERT, D. J.; REICHERT, J. M.; FLEIG, F. D.; RODRIGUES, M. F. GELAIN, N. S. Propriedades físicas e químicas de um Argissolo sob cultivo de Eucalyptus dunnii Maiden no Pampa gaúcho. Ciência Florestal, Santa Maria, v. 28 n. 2, p. 580 - 590, 2018.

SAMPIETRO, J. A.; LOPES, E. S. Compactação de um cambissolo causada por máquina de colheita florestal especializada com geoestatística. Floresta, Curitiba, PR, v. 46, n. 3, p. 307 - 314, 2016.

SAMPIETRO, J. A.; LOPES, E. S; REICHERT, J. M. Compactação causada pelo tráfego de feller buncher e skidder em um Neossolo regolítico sob distintas umidades. Ciência Florestal, Santa Maria, v. 25, n. 1, p. 239 $248,2015$.

SAMPIETRO, J. A.; LOPES, E. S. Compactação de um Cambissolo e Neossolo submetidos a diferentes intensidades de tráfego de Feller Buncher e Skidder. Scientia Forestalis, Piracicaba, v. 39, n. 90, p. 265 - 272 , 2011.

SEIXAS, F. Potencial de danos dos sistemas de colheita de madeira no solo e nas cepas. Série Técnica do IPEF, n. 30, p. 63 - 78, 1997.

SILVA, C. A. T.; CEZAR, T. C. M.; NÓBREGA, L. H. P. Porosidade de Latossolos e práticas de manejo agrícola para a conservação do solo. Revista Varia Scientia Agrárias, v. 2, n. 2, p. 153 - 164, 2011.

FLORESTA, Curitiba, PR, v. 50, n. 4, p. 1837 - 1843, out/dez 2020.

Vargas, F. et.al.

ISSN eletrônico 1982-4688

DOI: $10.5380 /$ rf.v50 i4. 66186 
SPERANDIO, H. V.; CECÍLIO, R. A. Atributos físicos do solo em área sob colheita florestal semimecanizada no estado do Espírito Santo. Revista Ciência Agrícola, v. 15, n. 2, p. 69 - 74, 2017.

STRECK, E.V.; KÄMPF, N.; DALMOLIN, R.S.D.; KLAMT, E.; NASCIMENTO, P.C.; SCHNEIDER, P. Solos do Rio Grande do Sul. Porto Alegre: Emater, Rio Grande do Sul, Universidade Federal do Rio Grande do Sul UFRGS, 2002. 107 p.

SZYMCZAK, D. A.; BRUN, E. J.; REINERT, D. J.; FRIGOTTO, T.; MAZZALIRA, C. C.; LÚCIO, A. D.; MARAFIGA, J. Compactação do solo causada por tratores florestais na colheita de Pinus taeda L. na região sudoeste do Paraná. Revista Árvore, Viçosa, v. 38, n. 4, p. 641 - 648, 2014.

WREGE, M. S.; STEINMETZ, S.; REISSER JÚNIOR, C.; ALMEIDA, I. R. de. Atlas climático da região Sul do Brasil: estados do Paraná, Santa Catarina e Rio Grande do Sul. Brasília, DF: Embrapa, 2012, 334 p. 